\title{
Shifting Security in the South Caucasus
}

Richard Giragosian *

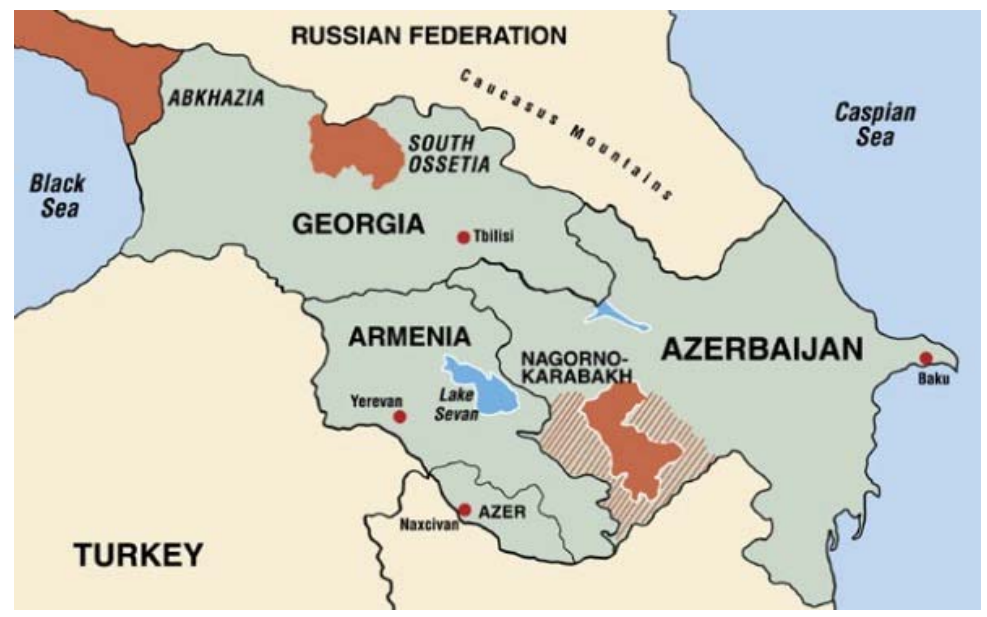

(map source: RFE/RL)

\section{Introduction}

The region of the South Caucasus has long served as a key arena for competing regional players and, for much of the past two centuries, has been hostage to the competing interests of much larger regional powers. Those very same historic powersRussia, Turkey, and Iran-continue to exert influence as today's dominant actors in the region. But, most significantly, this combination of historical legacies and current realities now constitutes a rapid shift in regional security. This shift in security incorporates not only several general elements, ranging from the challenges of energy security to the constraints imposed by several unresolved or "frozen" conflicts, but also more specific trends, including a new, deeper level of engagement by both NATO and the European Union.

Against the backdrop of a dynamic shift in the security environment, the three states of the South Caucasus region-Armenia, Azerbaijan, and Georgia — each face a difficult course of economic and political reform, systemic transition, and nation building. The region also continues to struggle in overcoming the legacy of constraints and challenges stemming from seven decades of Soviet rule. But it is the more recent

* Richard Giragosian is a Washington-based analyst specializing in security, politics, and economics in Eurasia and the Asia-Pacific and is a frequent contributor to the publications of Radio Free Europe/Radio Liberty (RFE/RL) and the Jane's Information Group, among others. For much of 2007, he has been conducting field research in the South Caucasus. 
intersection of interests among greater powers that tends to place this region, more than many others, in danger of returning to serving as an arena for confrontation.

\section{Shifting Security}

Throughout much of the 1990s, Western policies toward the South Caucasus region were dominated by considerations related to the development of the Caspian Sea energy reserves and the challenges of securing export routes amid the competing interests of the regional powers. This long-standing Western focus on energy has more recently been superseded, however, by a pursuit of security and stability, reflecting a substantially revised strategic agenda.

The Western pursuit of security and stability has been marked by a complex diversity, and occasional divergence, of interests for Armenia, Georgia, and Azerbaijan. More specifically, this altered strategic perception of the region has been driven by three specific factors.

\section{A New Strategic Significance}

Access and Power Projection. The first factor that has altered the strategic view of the South Caucasus has been the set of demands for access and power projection essential for the military campaign that has come to be known as the "global war on terrorism." This has meant that "air corridors" through the South Caucasus connecting military bases in Europe to "forward operating bases" in Central Asia have replaced oil and gas pipelines as the West's strategic priorities. This has also resulted in the emergence of the United States as not only a new "military power" in Central Asia, but in a series of direct moves establishing the U.S. as a military presence in the South Caucasus for the first time in history.

A Subset of U.S.-Russian Relations. A second factor contributing to a new strategic context for the South Caucasus has been the region's role as a subset of much larger relations between the United States and the Russian Federation. During the onset of this new strategic landscape, the foundation for the U.S. approach to the region was initially tied to the dynamically new "strategic partnership" between the United States and Russia initially forged in the wake of 11 September 2001. The definition of that new post-September 11 geopolitical reality was no longer in terms of a zero-sum game, but one of shared threats and common enemies within the context of the war on global terrorism.

But, as has become evident in the past few months, the new strategic partnership between the U.S. and Russia has not been without its share of strains and struggle. Moreover, the South Caucasus (and Central Asia, for that mater) represents an arena for both cooperation and competition. The region is unique in this way, by virtue of its geographic and geopolitical vulnerability as a region where the national interests of Russia, Turkey, Iran, and the United States all converge. The most obvious example of the region's vulnerability is seen in Georgia, which has emerged as a "frontline" state through its attempts to confront Russian pressure and to enter the NATO alliance, all 
the while moving much closer to Europe than its neighbors, and doing so much more rapidly.

Proximity to Iran. Third, another geography-driven factor fostering a new strategic environment for the region is the proximity of the South Caucasus to Iran. As with the first two factors, this third component of the new strategic view of the region also reflects military considerations. Of the three states of the region, only Azerbaijan and Armenia hold especially significant considerations in relation to Iran, rooted in the natural appeal of Azerbaijan as a platform for military engagement and in the potential for Armenia to serve as a "bridge" for economic and political engagement with Iran.

\section{EU Engagement}

Each of these three factors contributes to a new strategic context for the South Caucasus. And it is no accident that each of these factors reflects an overriding military-security consideration. But this new strategic environment is not solely an extension of a revised U.S. view of the region. It is also evident in the more recent European Union policy of engagement in the South Caucasus.

More specifically, for the EU this policy of engagement relates to a deeper strategy of securing the border areas along the EU's periphery. In terms of security, the geography of the region is a crucial metric for the EU and the United States. And for both, geography is also about the strategic significance of the "two seas"-The Black Sea and the Caspian Sea-with an enhanced focus on emerging transnational threats (proliferation, narcotics, terrorism, etc.). For the EU, the basis of its interest in the Black Sea region stems from the proximity of Greece, the membership of Romania and Bulgaria in the EU, and the promise of Turkey's candidacy. But the EU "Black Sea Synergy" strategy of April 2007 also significantly expanded the Black Sea region to include both Armenia and Azerbaijan, not as littoral states but as "natural regional actors."

The EU's engagement in the region is also a component of a strategy of broader engagement with Central Asia. Through the application of so-called "Action Plans," the EU has formulated a tailored blueprint for engaging each state, based on a calculus defined by the status of each state's political, economic, and social reforms. Through the individual Action Plan instruments, the path of EU political engagement is as important as the outcomes-it is the process that matters most. The viability of a given state's EU candidacy is much less important, with a focus on evolutionary development over revolutionary change, or on the need for stability.

Thus, for EU engagement, the real key to durable stability and security in the region is rooted more in the internal considerations of economic reform and political democratization than in any external factors. But in a larger sense, the engagement of the EU also manifests a dual approach of going "one step beyond" Turkey and "one step closer" to Iran. And it is the question of Iran that will only further impact the region's strategic landscape. 


\section{Energy and (In)Security}

The significance of energy security has gained renewed attention in recent years, driven by a sharp and historic rise in oil prices, defined by concerns over mounting structural dependence on Middle Eastern energy suppliers and demonstrating a new recognition of the threat of climate change. The challenge of energy security represents neither a new nor especially novel priority for the United States, yet its linkage to U.S. national security has never been as clear or as pressing. While the U.S. pursues energy security as part of a broader strategy of seeking a greater diversity of both supply and suppliers, the imperative for the European Union (EU) is a more immediate concern: the need to overcome its mounting structural dependence on imports of Russian gas. Yet both the U.S. and the EU recognize energy security as an integral component of national security. For Russia, however, a new definition of energy security applies, whereby energy is actually more of a coercive implement than an element of national security - one that can be exercised to regain power and influence within the former Soviet space and to restore international geopolitical significance.

Within this context, the issue of energy security in the region of the South Caucasus offers a particularly insightful look at the intersection of these clashing interests, as an arena for both cooperation and competition. Further, the region also demonstrates that energy security is as much a component of regional security as it is an element of national security; in this way, energy holds the key to both security and stability in this strategically important region. But the most significant factor in regional energy security has been its vulnerability to Russian pressure, with energy as an essential tool for leverage.

\section{Russia's Use of Energy as Leverage}

Through much of the 1990s, Russia's policy was driven by a need to protect its waning power over the newly independent former Soviet states. The infant states comprising Russia's so-called “near abroad” were especially vulnerable to their shared Soviet legacy of reliance on Russia for trade, transport, and energy. These structural vulnerabilities were only heightened by the daunting challenges of a transition marked by severe economic decline and state sovereignty threatened by a series of ethnic conflicts and border disputes.

The preservation of Russian power in this early period relied on a combination of outright intimidation and intervention, played out against a backdrop of new conflicts and ethnic tension. Yet Russia's attempt to protect its vastly degraded influence and power were limited in turn by its own decline and the conflict in Chechnya. By 1999, however, there was a shift in Russian policy with the ascension of Vladimir Putin to the Russian presidency. The shift was marked by a graduation from the basic preservation of Russian power to the projection of Russian power and influence. Under Putin, a new, much more effective tactic was developed, based on the use of energy as a tool for consolidating and projecting power. This strategic use of energy leverage emerged as the new standard for Russia, in effect replacing the more traditional reliance on "hard power" politics with a new exercise of "soft power." 
Despite its development as a tool for power projection, this Russian use of energy resources for extorting as much as exporting was not new. The Russian energy position was clearly a major element in Soviet policy and was based on the Soviet system's structure of core-periphery relations as a classic model of dependence. Even in the waning days of the Soviet Union, energy was a weapon of first resort in attempting to contain the rumblings of the early independence movements in the Baltic states. Even during the Yeltsin period, Moscow routinely utilized energy to pressure both the Baltics and Ukraine. For today's Russia, such a strategy is seen as an updated concept, based not on the traditional view of energy security defined by the reliability and diversification of energy suppliers, but as a concept of energy security actually defined by energy as security, or more specifically, energy as an element of security policy.

This Russian inclusion of energy as a pillar of its security policy consists of three core components. First, it has been able to project Russian power and influence within the so-called "near abroad" of former Soviet states along Russia's periphery. The success of this tactical adaptation is most clearly demonstrated by Russia's steady accumulation of control and even acquisition of much of the energy sectors in states in the South Caucasus and Central Asia. Second, Russia's use of energy also served as a tool for strengthening state power. This was more than simply filling state coffers with greater energy revenue, however, as it more broadly empowered Russian status as both a regional and even Asian power. Third, the Russian energy gambit provided an attractive way to restore the country's international significance and regain its reduced geopolitical relevance.

There is a broader strategic dimension to Russia's tactical use of energy leverage, however. The Russian strategic perspective views energy as an integral part of an overall projection of Russia power and position. It is energy that most clearly marks an eastward Russian shift, away from Europe and toward Asia. As an aspiring Asian power, Russia sees an opportunity for greater engagement, as can be seen in the case of its participation in the six-party talks over North Korea, as well as in the recent warming of its relations with Japan. In fact, Moscow sees no real threat or challenge from Japan (other than the unresolved territorial dispute). But it views China more as a rival power, and despite its rather reluctant partnership with Beijing, Moscow is consumed by a fear of Chinese expansion and penetration into the vulnerable Far East.

Although the use of energy leverage has been one of the most visible outward signs of Russia's strategic vision, there is a second stage to this strategy. Specifically, the imposition of sharp price increases for Russian natural gas imports to the highly dependent former Soviet states was driven not simply by a desire for either more revenue or to adjust subsidized prices to global market levels. The longer-term goal was to foster greater dependence by forcing the neighboring consumer states to accumulate greater arrears for Russian gas imports. It was envisioned that, as these importing states had neither the money to pay for the higher priced gas nor the time to secure alternative supplies, Russia would be able to either acquire a dominant share in these countries' energy sectors outright or accumulate control over their pipelines.

There is also a Russian imperative to maximize its energy position in the face of inherent weakness. In this way, Russia's effective use of energy as leverage is still 
largely limited by fundamental weakness over the longer term. For example, despite the tactical gains from the use of energy as leverage, Russia's energy sector remains beset by four serious shortcomings: it has no unutilized capacity; its oil is relatively expensive to produce; it has limited pipeline capacity; and it is still far from being a truly global energy player.

Moreover, this weakness is compounded by a second long-term weakness, namely the fact that the more Russia plays the energy card for short-term leverage and pressure, the more damage it causes to its reputation and standing as a reliable energy ally, thereby only undercutting its broader strategy to regain its global role and relevance. This was the result of the Russian cutoff of gas supplies to Ukraine and Georgia in January 2006, as well as its three-day cutoff of gas to Belarus almost exactly one year later.

\section{Russia's New Security Stance}

Against this backdrop of recognizing the energy strategy's limited utility and perceiving the underlying weakness to which it points, there are new signs in Moscow revealing a shift in planning to a renewed Russian commitment to bolstering its beleaguered military, only exacerbated by a more confrontational stance toward the United States. Yet this is not so much a shift in tactics; rather, it is more of a demonstration of the dynamic scale and scope of Russian strategy.

More specifically, there is a much deeper complexity in the still emerging Russian security strategy. The defining imperative for its security policy is rooted in a dynamic concept of "Fortress Russia," whereby the paradox of a strong state beset by a weak economy is overcome through policies of economic re-nationalization, geopolitical reassertion, and the restoration of "great power" status.

Most recently, Russian security policy has both adopted and adapted new elements, with President Putin now implementing a deeper strategy, well beyond the use of energy simply as leverage, by imposing commodity-based embargoes as part of a broader strategy designed to promote and consolidate Russian dominance over the terms and patterns of trade in the former Soviet regions. Yet, just as the long-term use of energy as the key for reasserting power and influence is limited by Russia's fundamental weaknesses, this second strategic element of using trade embargoes to forge market or trade dominance is bound to fail. Similar to the meager economic (and political) results of trade sanctions and embargoes throughout the world, it is clear that there is an inverse relationship whereby the impact of punitive measures consistently declines following their initial imposition.

In other words, there is a declining level of effect in both economic and political terms, as markets adapt to such measures and states adopt new policies or partners. The failure of such punitive trade measures is only exacerbated by the dynamic composition of today's increasingly globalized marketplace, which has introduced greater flexibility in the market relations and ties between states, both as suppliers and consumers and as exporters and importers.

Such a failure can already be seen in the case of the Russian embargo on Georgia, for example. The Georgian wine and mineral water industries have already begun to 
forge new trade ties beyond their traditional markets into Asia, Europe, and North America. Despite having suffered immense losses, Georgia's experience demonstrated that, so long as a nation's products or commodities are competitive on a global economic scale, the punitive cutoff or disruption in its traditional markets is a one-time "shock" that is rapidly overcome or even negated by the flexibility and adaptive response of the market.

Although the benefits for Russia from the commodity-based embargo are clearly less than hoped for or even expected by Moscow, the seemingly political or even "public relations" returns from the punitive move against Georgia may mean that Moscow will hesitate before admitting that, ironically, the economic impact of the embargo did more to bolster Georgian competitiveness and productivity than to give Russia a stronger hand. Therefore, there is a looming danger that Moscow may soon overplay its strategy for forging a "Fortress Russia." The implications from such a Russian miscalculation may not only impact the oil and gas markets in the short term, but may also seriously alter the longer-term development of regional energy infrastructure, from the Caspian Sea to Central Asia. But, most notably, the Russian impact on energy security will also continue to drive the strategic trajectory of Western engagement in both the South Caucasus and Central Asia.

\section{Conclusion}

Thus, the course of Western engagement in the region has been a mixed bag, driven by a set of competing interests and defined by a series of converging and diverging policies. Yet it seems apparent that the regional transition now underway will only serve to exacerbate the growing divide between the West and Russia. This regional transition, with the Armenian elections as the opening round, will only continue, with presidential elections in both Armenia and Azerbaijan, and presidential and parliamentary elections in Georgia in 2008. Additionally, the region will also be impacted by next year's elections in both Russia and the United States.

For security in the South Caucasus, however, the real imperatives are internal in nature, stemming from several key challenges: the need to graduate from the political school of elections driven by power instead of politics, and leadership determined more by selection than election. Legitimacy is the key determinant of durable security and stability, while the strategic reality of the region is defined less by geopolitics, and more by local politics and economics. But most crucial is the lesson that institutions matter more than individuals for real democratization. Consequently, it is the regimes themselves that hold the key to their future. And while Western engagement is important, real stability and security depend more on the legitimacy of regional governments, and on local economics and politics, than simply a reliance on grand geopolitics. 